\title{
THE ESCHATOLOGY OF THE WARNING IN HEBREWS 10:26-31
}

\author{
Randall C. Gleason
}

\section{Summary}

The absence of NT damnation terminology in Hebrews calls into question the widely held assumption that the author's purpose was to warn his readers of eternal judgement. Furthermore, to limit the warnings to a distant future judgement overlooks its nearness and diminishes its relevance to the first-century audience facing the dangers arising from the first Jewish revolt. There are many clues throughout the epistle that point to the physical threat posed by the coming Roman invasion to those Christians who lapsed back into Judaism. These clues point immediately to the destruction of Palestine, the city of Jerusalem and the Temple. These conclusions are confirmed by a close examination of the OT texts cited or alluded to in Hebrews 10:26-31. Rather than eternal destruction, the OT examples warn of physical judgement coming upon Israel because of covenant unfaithfulness. If they sought refuge in Judaism, the readers could suffer the same fate of the Jewish rebels by the Romans. However, the readers could avoid God's wrath coming upon the Jewish nation by holding firm to their confession, bearing the reproach of Christ outside the camp (13:13), and looking to the heavenly city instead of Jerusalem now under the sentence of destruction (13:14).

\section{Introduction}

Though many have analysed the eschatology of Hebrews, ${ }^{1}$ few have discussed its importance to the controversial warning passages. ${ }^{2}$ Five

1 C.K. Barrett, 'The Eschatology of the Epistle to the Hebrews', The Background of the New Testament and Its Eschatology, eds. W.D. Davies \& D. Daube (FS C.H. Dodd; Cambridge: CUP, 1953), 363-93; C.E. Carlston, 'Eschatology and Repentance in the Epistle to the Hebrews', JBL 78 (1959) 296-302; L.D. Hurst, 'Eschatology and "Platonism" in the Epistle to the Hebrews', SBL Seminar Papers 23 (1984) 41-74; G.W. MacRae, 'Heavenly Temple and Eschatology in the Letter to the Hebrews', Semeia 12 (1978) 179-99; W.C. Robinson, 'Eschatology of the Epistle to the Hebrews: A study in the Christian Doctrine of Hope', Encounter 22 (1961) 37-51; J.R. Sharp, 'Philonism and the Eschatology of Hebrews: Another 
times the author exhorts his readers to remain faithful by warning them of coming judgement. ${ }^{3}$ Each warning becomes increasingly more severe culminating in the threat of fiery judgement that 'will consume the adversaries' (10:27) and bring 'destruction' (10:39). Many link this catastrophic event to the judgement immediately following the 'second' coming of Christ (9:27-28) and therefore assume that Hebrews 10:26-31 warns of 'eternal judgement' or 'damnation' (9:27). ${ }^{4}$ Others regard it as a warning of severe physical punishment leading to loss of life but not final judgement. ${ }^{5}$ This would explain the noticeable absence of 'damnation' terminology commonly found throughout the New Testament and contemporary Jewish literature. ${ }^{6}$ When speaking of final judgement Jesus warned of

Look', EAJT 2 (1984) 289-298; and M. Silva, 'Perfection and Eschatology in Hebrews', WTJ 39 (1976) 60-71.

2 Two notable exceptions are S.D. Toussaint, 'The eschatology of the warning passages in the Book of Hebrews', GTJ 3 (1982) 67-80 and T.K. Oberholtzer, 'The warning passages in Hebrews: The eschatological salvation of Hebrews 1:5-2:5', BSac 145 (1988) 83-97.

3 The author of Hebrews is assumed to be male since he uses the masculine participle $\delta \imath \eta \gamma o v ́ \mu \varepsilon v o v$ in Heb. 11:32 to designate himself. See A.H. Trotter, Jr. Interpreting the Epistle to the Hebrews (Grand Rapids: Baker, 1997), 42, note 5.

4 Toussaint, 'The Eschatology of the Warning Passages in the Book of Hebrews', 67, 78-79; S. McKnight, 'The Warning Passages of Hebrews: A Formal Analysis and Theological Conclusions', TJ 13 (1992) 34, 54; R.A. Peterson, 'Apostasy', Presbyterion 19 (1993) 24-28; P. Ellingworth, The Epistle to the Hebrews (NIGTC; Grand Rapids: Eerdmans, 1993), 541-43; B.M. Fanning, 'A Theology of Hebrews', in A Biblical Theology of the New Testament, eds. R.B. Zuck \& D.L. Bock (Chicago: Moody, 1994), 407-409; T.R. Schreiner \& A.B. Caneday, The Race Set Before Us: A Biblical Theology of Perseverance \& Assurance (Downers Grove: InterVarsity, 2001), 199-202.

5 M.A. Eaton, No Condemnation: A New Theology of Assurance (Downers Grove: InterVarsity, 1995), 212, 216; G.H. Lang, The Epistle to the Hebrews (London: Paternoster, 1951), 176-83; D.A. Dunham, An Exegetical Examination of the Warnings in the Epistle to the Hebrews (Th.D. diss., Grace Theological Seminary, 1974), 212-14; T.K. Oberholtzer, 'The Danger of Willful Sin in Hebrews 10:26-39', BSac 145 (1988) 412-15.

6 For example, Apoc. Zeph. describes the angels casting 'the souls of ungodly men ... into their eternal punishment' (4:7) and Hades as a place of 'torment' (10-11). 4 Ezra depicts 'the furnace of Hell' as a place of 'fire and torment' (7:36, 38). According to 2 Baruch, 'the habitation' of the wicked 'will be in the fire' (44:15) where they will be 'tormented' $(51: 6 ; 54: 14) .4$ Maccabees warns against 'eternal torment by fire (9:9)', 'eternal destruction' (10:15) and 'eternal fire and tortures...throughout all time' (12:12). The Rule of the Community from Qumran warns against 'eternal damnation... without end with the humiliation of destruction by the fire of the dark regions' (1QS 4:12-13). Though rare, we do find similar language in the OT of eternal punishment in the after-life. For example, Daniel

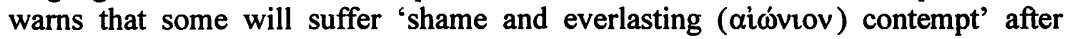
death (12:2 LXX). Likewise, the Lord warns Tyre of final judgement 'in the pit', 
the 'unquenchable fire of hell' (Mt. 5:22; 18:9; Mk. 9:43-48), 'eternal fire' (Mt. 18:8; 25:41), and 'eternal punishment' (Mt. 25:46). Similarly other NT authors spoke of 'eternal destruction' (2 Th. 1:9) and 'punishment of eternal fire' (Jude 7). In light of the frequent use of the term 'eternal' ( $\alpha i \omega$ vios) throughout Hebrews (5:9; 6:2; 9:12, 14,$15 ; 13: 20$ ), its absence in the warning passages is significant, particularly if the author intended to warn his readers against the finality of judgement in the life to come. ${ }^{7}$ Final judgement mentioned in Hebrews 9:27 occurs after death ('it is appointed for men to die once and after this [comes] judgement') and therefore should be distinguished from the immediate threat they 'see...drawing near' in their present circumstances (10:25). Some have suggested that the author has in view the coming Roman invasion of Palestine that would soon bring an end to the Temple sacrifices (8:13) and the destruction of Jerusalem (13:14). ${ }^{8}$ If so, he could be warning his readers of physical harm or even death if they seek refuge in Judaism instead of Christ. This study seeks to understand the severity of the warning in Hebrews 10:26-31 through an examination of its. Old Testament citations and allusions in light of the impending destruction of Palestine, Jerusalem, and the Temple during the first Jewish revolt (AD 66-70).

\section{The Historical Context of Hebrews}

The difficulty in determining the precise occasion for this epistle has lead some to disparage attempts to determine the historical sitting of the readers. 9 Though the exact date and location of the audience cannot be determined with absolute certainty, a general setting is not

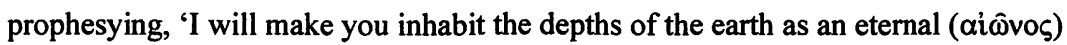
wilderness' (Ezk. 26:20 LXX).

7 His one reference to 'eternal judgement' (6:2) is listed among the 'elementary teachings' $(6: 1)$ he exhorts his readers to leave behind. Though it is possible that 'eternal judgement' may refer to the danger of being 'cursed' and 'burned' (6:8), the grammar and flow of thought in the context provides no reason to link them.

8 P.W.L. Walker, Jesus and the Holy City: New Testament Perspectives on Jerusalem (Grand Rapids: Eerdmans, 1996), 230-34; J.D. Pentecost, 'The Apostles' Use of Jesus' predictions of Judgment on Jerusalem in $\mathrm{AD} 70$ ', in Integrity of Heart, Skillfulness of Hands, ed. C.H. Dyer \& R.B. Zuck (FS D.K. Campbell; Grand Rapids: Baker, 1994), 140-41; M. Dods, 'The Epistle to the Hebrews', The Expositor's Greek Testament, ed. W. R. Nicoll (Grand Rapids: Eerdmans, reprinted 1979), 4:347-48.

9 L.D. Hurst discourages attempts to identify the historical circumstances of Hebrews: 'While such speculative reconstructions are popular, in the end they are totally unnecessary' ('New Testament Theological Analysis', Introducing New Testament Interpretation, ed. S. McKnight [Grand Rapids: Baker, 1989], 155-56). 
only possible but also necessary to establish the author's intended meaning. The epistle clearly addresses a distinct Christian community $(5: 11-12 ; 6: 10 ; 10: 25)$ facing a particular set of circumstances $(10: 32-34 ; 12: 4 ; 13: 3,7,23)$. In spite of the obstacles we must not ignore the impact of these circumstances on the meaning of the text. Several features of the epistle reveal important clues to the identity and general historical setting of the readers.

Most interpreters date the epistle prior to the destruction of Jerusalem and the Temple in $\mathrm{AD} 70$ for the following reasons. ${ }^{10}$ First, the author's strong polemic against returning to the sacrificial system (e.g. $6: 6 ; 10: 26,29$ ) would seem pointless unless sacrifices were still being offered in the Temple. 11 Second, the manner in which the sacrificial system is described suggests that the Temple cult was still operational. This conclusion seems unavoidable in light of the author's claim that 'the outer tabernacle is still standing' as 'a symbol for the present time' (9:8-9) and its sacrifices have not ceased but continue as 'a reminder of sins year by year' (10:2-3). ${ }^{12}$ Third, if the epistle

10 Advocates of a pre-70 date include G.W. Buchanan, To the Hebrews (Garden City: Doubleday, 1972), 261; D.A. Hagner, Hebrews (San Francisco: Harper, 1983), xviii-xix; P.E. Hughes, A Commentary on the Epistle to the Hebrews (Grand Rapids: Eerdmans, 1977), 30-32; B. Lindars, The Theology of the Letter to the Hebrews (Cambridge: CUP, 1991), 19-21; J.A.T. Robinson, Redating the New Testament (Philadelphia: Westminster, 1976), 200-220; C. Spicq, L'Epitre aux Hébreux (2 vols.: Paris: Gabalda, 1952), 1.253-61; A. Strobel, Der Brief an die Hebräer (Göttingen: Vandenhoeck \& Ruprecht, 1975), 83; Trotter, Interpreting the Epistle to the Hebrews, 33-36; and Walker, Jesus and the Holy City, 227-32. Those who argue for a later date include R.E. Brown, An Introduction to the New Testament (New York: Doubleday, 1997), 696-7; L. Goppelt, Theologie des Neuen Testaments (Göttingen: Vandenhoeck \& Ruprecht, 1976), 570; and W.G. Kümmel, Introduction to the New Testament (London: SCM, 1975), 403.

11 Walker, Jesus and the Holy City, 228. Paul's attempt in AD 57 to avoid trouble with those 'zealous for the law' by visiting the Temple for purification and sacrifice (Acts 21:20-28) illustrates the pressure faced by Jewish Christians to return to the sacrificial system.

12 See Hughes' list of 18 present tense descriptions of the Levitical priesthood in Hebrews (Hebrews, 31-32). Some dismiss the significance of the present tense due to its similar use by Josephus (Ant. iv. 102-87) and Clement of Rome (1 Clem. 41) in their discussions of the Tabernacle long after the demise of the Temple (e.g. J. Moffatt, $A$ Critical and Exegetical Commentary on the Epistle to the Hebrews [ICC, Edinburgh: Clark, 1924], xxii). However, this proves only that the dating of Hebrews cannot be established by tense alone. But when considered in light of the author's polemic against returning to the sacrificial system and his silence about the destruction of the Temple, his present-tense descriptions of the Jewish sacrifices remain compelling arguments for a pre-70 date. Walker explains how the use of 'tabernacle' ( $\sigma \kappa \eta v \eta)$ instead of 'Temple' enabled the author 'to develop his argument at a strictly theological level.' Rather than entangle himself and his readers in the public debate regarding the sanctity of the physical Temple structure, he was able to point to the temporary purpose of the worship system at its root, i.e. 
was written after the destruction of the Temple the author's silence on the matter is 'almost inconceivable' since it would have clinched his argument that the old covenant had given way to the new. ${ }^{13}$ Finally, the readers' fears of death $(2: 15)$, persecution, and ostracism $(10: 32-34)$ correspond to the threats used by Jewish patriots to preserve Temple worship and promote political solidarity prior to their war with Rome (AD 66-70). ${ }^{14}$

A Jewish framework permeates the epistle in numerous ways. First, the author's abundant use of the Jewish scriptures assumes not only a deep familiarity with the OT among his readers but also the recognition of its binding authority over their lives (2:2). Second, his points of comparison with Jesus Christ are all drawn from the Jewish world. Only the Jews were united in their concern for Moses $(3: 1-6)$, the Levitical priesthood (7:1-28), the Day of Atonement (9:7), and the various symbols of Jewish worship (9:1-22). And only among the Jewish sect at Qumran do we find a similar interest in the mysterious OT figure of Melchizedek (5:6, 10; 7:1-10; cf. 11QMelch). The Son's superiority over the angels (1:4-2:16) also had unique relevance to the veneration of angels in Second-Temple Judaism. ${ }^{15}$ Third, the obsolescence of the Jewish priesthood, Temple, and sacrifices (8:1-10:18) had greatest significance to a Jewish audience. Fourth, the author's appeal to various aspects of Jewish apocalyptic thought (see next section) also suggests Jewish recipients. While the dominance of Jewish background does not conclusively prove a pure Jewish readership, it calls into question attempts to root the author's

its 'pristine form under Moses' in the wilderness. Yet, it seems unlikely that the readers could miss the implications of this truth to their contemporary situation. God's establishment of a new 'altar' (Heb. 13:10) would mean 'the end of the Jerusalem Temple as they had known it' (Jesus and the Holy City, 207-8).

13 Lindars, Hebrews, 20. See also Hughes, Hebrews, 30; Robinson, Redating, 202.

14 That Christians suffered from Jewish patriots zealous for law and Temple is clear from the NT (e.g. Acts 6:11-14; 9:1; 12:1-3; 21:27-31; 1 Th. 2:14-16; 2 Cor. 11:24; Gal. 4:29; 6:12). Josephus recounts the case of James, the brother of Jesus, who was executed by the High Priest for 'having transgressed the law' (Ant., xx. 200). Violent attacks intensified upon all those who refused to show solidarity with the Jewish resistance prior to the war (J.W., ii.264-65); B. Reicke, 'Judaeo-Christianity and the Jewish establishment, $\mathrm{AD}$ 33-66', Jesus and the Politics of His Day, eds. E. Bammel \& C.F.D. Moule (Cambridge: CUP, 1985), 145-52.

15 The widespread Jewish fascination with angels is evident from the Qumran writings (e.g. 1QM 8:14-17; 12:1-9; 4Q529), Jewish amulets with inscriptions calling on angels for help and protection, and other contemporary Jewish literature (e.g. Tobit, 1 Enoch 66-69). See C.E. Arnold, The Colossian Syncretism (Grand Rapids: Baker, 1996), 32-60 and L.T. Stuckenbruck, Angel Veneration and Christology (Tübingen: Mohr, 1995), 192-200. 
theology and eschatology in other Hellenistic thought-forms such as Platonism or Gnosticism. 16

Of the numerous destinations suggested for the epistle to the Hebrews, Rome and Palestine have received the greatest attention. If Rome was the destination, as indicated by the salutation 'Those from Italy greet you' (13:24), the sufferings of the readers (10:32-34) may describe the hardships endured by the Jewish Christians expelled from Rome by the edict of Claudius in AD 49 (e.g. Acts 18:2). ${ }^{17}$ The fact that Hebrews 1 was cited by Clement of Rome (1 Clem. 36) may further indicate its earliest readers lived in Rome. However, these evidences do not rule out a Palestinian audience. The final greeting (i.e. Heb. 13:23) is far from conclusive since it could also indicate its origin 'from' Italy rather than its destination. ${ }^{18}$ And a pre-70 date would provide ample time for the epistle to circulate beyond Palestine accounting for its use by Clement of Rome late in the first century ( $c$. $A D$ 96). The book's emphasis upon the Jewish sacrificial system has convinced many that the readers lived somewhere in Palestine. 19 Their 'former days' of suffering (Heb. 10:32-34) could refer to the Jewish persecution of Christians in Judaea following Pentecost (e.g. 1 Th. 2:14-15; Acts 9:1; 12:1-2). The claim, 'You have not yet resisted to the point of shedding blood' (Heb. 12:4) would appear to rule out the Jerusalem church that suffered the early martyrdom of Stephen (Acts 7:57-60) and later James (Acts 12:1-2). However, this would not rule out other Christian communities located throughout greater Palestine who continued to feel the attraction of the Temple sacrifices. Neither does the author's extensive use of the Septuagint (LXX) render a Palestinian destination less likely since Hellenistic Jews made up a significant portion of the early church in Judaea (e.g.

16 Although the impact of Hellenism was great, the Hebrew scriptures remained the primary literary influence upon second-temple Judaism. Lindars provides a helpful summary of the impact of Hellenistic Judaism upon the book of Hebrews while dispelling the alleged influences of Qumran, Philo, Platonism, and Gnosticism (idem, The Theology of the Letter to the Hebrews, 21-25). See also Hurst, 'Eschatology and "Platonism" in the Epistle to the Hebrews'.

17 Advocates of a Roman destination include W.L. Lane, Hebrews 1-8 (WBC, Dallas: Word, 1991), lviii-lx; F.F. Bruce, The Epistle to the Hebrews (Grand Rapids: Eerdmans, 1964), xxxi-xxxv; Brown, Introduction, 699-701.

18 The traditional title 'to the Hebrews' found in several manuscripts represents an early tradition identifying the recipients as Jewish Christians. The additional

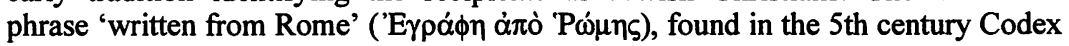
Alexandrinus (A), is particularly noteworthy. See Hughes, Hebrews, 16, note 16.

19 Advocates of a Palestinian destination include Buchanan, To the Hebrews, 256-60; Spicq, L'Epître aux Hébreux, 1.247-50; and F.J. Delitzsch, Commentary on the Epistle to the Hebrews (2 vols. Edinburgh: T. \& T. Clark, 1871-72), 1.21. 
Acts 6:1-6). ${ }^{20}$ Walker further suggests that a Palestinian destination would add 'extra poignancy in Hebrews' description of Abraham as an 'alien in the promised land' (11:9),' for it would accurately describe the alienation suffered by the readers from their fellow countrymen. ${ }^{21}$ One of the strongest indications of a Palestinian setting is the author's exhortation to 'go ... outside the camp' (13:13) where Jesus suffered (13:11), that is the city of Jerusalem.22 His appeal to bear the 'reproach' of Christ 'outside the gate' would seem most applicable to those living near Jerusalem where Jesus was crucified as a criminal (13:12-13). For these reasons, a Palestinian destination remains a strong possibility.

Some claim the warnings are parenthetical to the main message and intended only for unbelievers mixed in among a Christian congregation. ${ }^{23}$ However, this seems unlikely since the strongest indications of a genuinely Christian audience appear within the warnings. This is particularly true in Hebrews 10 where those warned are described in ways that point to the genuineness of their 'confession' $(3: 1 ; 4: 14 ; 10: 22-23) .{ }^{24}$ First, the author warns those (including himself-'we') who had 'received the knowledge of the truth' (10:26) and been 'enlightened' (10:32). ${ }^{25}$ Rather than indicating a mere superficial knowledge of Christianity, this language suggests the turning point when they came to genuine faith in Christ. ${ }^{26}$ Second,

$20 \mathrm{M}$. Hengel has convincingly shown the pervasive impact of Hellenism upon Judaism in Palestine (Judaism and Hellenism [Philadelphia: Fortress, 1974], 311-12). Furthermore, the Greek Biblical texts found at Qumran and Nahal Hever provide ample evidence for the use of Greek Scriptures by the Hebrew speaking Jews living in Palestine. For examples see P.W. Skehan, E. Ulrich, \& J.E. Sanderson, Qumran Cave 4: Paleo-Hebrew and Greek Biblical Manuscripts (DJD IV; Oxford: Clarendon, 1992) and E. Tov, The Greek Minor Prophets Scroll from Nahal Hever (DJD IX; Oxford: Clarendon, 1990).

21 P.W.L. Walker, 'Jerusalem in Hebrews 13:9-14 and the Dating of the Epistle', TynBul 45 (1994) 68, note 52.

22 The similar use of 'outside the camp' designating Jerusalem in 4QMMT also reflects a Palestinian setting. In Pesher fashion, it reads, 'We have determined that ... [Je]rusale[m] is the 'camp', and that outside the camp [is 'outside of Jerusalem']. ... For Jerusalem is the holy camp. It is the place which He chose from all the tribes of Israel, for [Jer]usalem is the foremost of the c[a]mps of Israel' (4QMMT B:29-30; 60-61).

23 E.g. Peterson, 'Apostasy', 28.

24 If their baptismal confession of faith in Christ was not genuine, then why would the author repeatedly encourage them to hold fast to it?

${ }^{25}$ This corresponds to similar descriptions indicating the genuineness of their conversion in Hebrews 6:4-5. See further R.C. Gleason, 'The Old Testament Background of the Warning in Hebrews 6:4-8', BSac 155 (1998) 74-78.

26 Morris, 'Hebrews', 106; Ellingworth, Hebrews, 533. 
those warned not to 'regard as unclean the blood of the covenant' are declared 'sanctified' by that very covenant (10:29). ${ }^{27}$ Third, the promise that 'the Lord will judge His people' (10:30) suggests that severe punishment does come upon genuine Christians when they disobey. ${ }^{28}$ Fourth, the fact that those warned had already endured a great persecution is perhaps the strongest indication of the authenticity of their earlier conversion (10:32-36). ${ }^{29}$

\section{The Eschatology of Hebrews}

The 'already and not yet' scheme found elsewhere in the New Testament is crucial to understanding the eschatological outlook of Hebrews. ${ }^{30}$ The opening announcement that the 'last days' had arrived through God's revelation of his 'Son' (1:2) sets the stage for the author's 'inaugurated eschatology.' 31 First-century Jews endured their plight under foreign domination by focusing their hopes on the 'age to come.' 32 The Epistle to the Hebrews declares that this coming age had broken into human history through the advent of Christ and the completion of his high priestly work $(9: 11,26) .{ }^{33}$ The argument of

27 Since the author uses the word $\dot{\alpha} \gamma \mathbf{i} \zeta \omega$ ('sanctified') elsewhere of genuine Christians who Jesus 'has perfected for all time' $(10: 14 ;$ cf. $2: 11 ; 10: 10 ; 13: 12)$, it is difficult to accept W. Grudem's claim that he here uses $\alpha \gamma(\alpha) \zeta \omega$ to signify 'outward sanctification, not the internal sanctification that accompanies true salvation' ('Perseverance of the Saints: A Case Study from Hebrews 6:4-6 and the Other Warning Passages in Hebrews', in The Grace of God, The Bondage of the Will, 2 vols. ed. T R. Schreiner \& B.A. Ware [Grand Rapids: Baker, 1995], 177).

28 Bruce correctly concludes, 'This certainly means that He will execute judgment on ... behalf [of His people], vindicating their cause against their enemies, but also that ... He will execute judgment against them when they forsake His covenant' (idem, Hebrews, 262-63).

29 The typological relationship in Heb. 3:7-4:11 between those warned and the 'redeemed' yet rebellious generation of the Exodus (Ex. 14:30-15:18; cf. Heb. 11:29) also points to the genuineness of their conversion; see Gleason 'The Old Testament Background of Rest in Hebrews 3:7-4:11', BSac 157 (2000) 280-302.

30 See Fanning, 'A Theology of Hebrews', 404-405 and G.E. Ladd, $A$ Theology of the New Testament (Grand Rapids: Eerdmans, 1974), 575-77.

31 See Bruce, Hebrews, 3.

32 Regarding the eschatological expectations of first-century Judaism see E.P. Sanders, Judaism: Practice and Belief 63 BCE-66 CE (London: SCM; Philadelphia: Trinity, 1992), 279-303; N.T. Wright, The New Testament and the People of God (Minneapolis: Fortress, 1992), 244-338; R.A. Horsley, Jesus and the Spiral of Violence: Popular Jewish Resistance in Roman Palestine (Minneapolis: Fortress, 1993), 121-45; J.J. Scott, Jr., Customs and Controversies: Intertestamental Jewish Background of the New Testament (Grand Rapids: Baker, 1995), 265-333.

33 Eschatological references include 'the world to come' (2:5); 'the age to come' (6:5); 'the good things to come' $(9: 11 ; 10: 1)$; 'the consummation of the ages' 
the epistle demonstrates how the following elements of Jewish apocalyptic thought had been 'realised' in Jesus Christ. First, the Jews expected the arrival of a Davidic messiah who would rule over them as king. ${ }^{34}$ Hebrews declares Jesus to be the long-awaited messianic Son who had already sat upon his 'throne' (1:8) at God's right hand $(1: 2-3,13 ; 10: 12)$ to begin ruling his unshakeable 'kingdom' $(1: 8$; $12: 28)$. Second, the Jews longed for the day Yahweh would renew his covenant with his people (Je. 31:31-34; Ezk. 36:22-36; 37:26-28). Hebrews declares that Jesus had inaugurated the new covenant with better promises replacing the old (Heb. 8:6-13). Third, many Jews believed that covenant-renewal would require a new priesthood to provide purification for Israel's sins since the present priesthood had grown corrupt. ${ }^{35}$ The author of Hebrews presents Jesus as a permanent priest $(7: 11-28)$ without $\sin (4: 15)$ who provided complete purification once for all through his perfect sacrifice $(1: 3 ; 9: 11-14$; 10:10-14). Fourth, due to its desecration by violence and a corrupt and politicised priesthood many expected a renewed or rebuilt Temple. ${ }^{36}$ Hebrews declares that Jesus had built a new house (3:1-6; $10: 21)$ and provided access to the true tabernacle $(8: 1-10: 18)$ in the

(9:26); Christ's 'appear[ance] a second time' (9:28); 'the day drawing near' (10:25); and the repeated exhortations to hold firmly to 'our hope' and 'assurance $\ldots$ until the end' $(3: 6,14 ; 6: 1 ; 10: 23)$.

34 The rule of the Davidic son promised in the OT (2 Sa. 7:4-16; Je. 23:5-6; 30:9; Ezk. 34:24; 37:24-25; Ho. 3:5) is described in more militant terms in Ps Sol. 17:4-5, 21-46 and at Qumran (CD 19:10-13; 4QpGena 5:1-6; 4QpIsa 3:1-25; 4QFlor 1:7-13); cf. K. Atkinson, 'On the Herodian Origin of Militant Davidic Messianism at Qumran: New Light from Psalm of Solomon 17', JBL 118 (1999) 435-60.

35 Many report corruption among the priesthood including Josephus (Ant., xx. $186-87 ; 216-18 ; 247)$, the Qumran texts (1QpHab 8:8-9:9; 12:2-10; CD $4: 17-5: 11 ; 6: 15-16)$, and $T$. Levi , 14:5f. For a summary of 'the notorious events associated with the high priesthood in the period before $\mathrm{AD} 70^{\circ}$ and their impact on Hebrews, see D. Mendels, The Rise and Fall of Jewish Nationalism (Grand Rapids: Eerdmans, 1997), 316-18. Consequently, many expected a new priest to raise up who would usher in a new era of holiness (T. Levi 18.2-14) and reign as an eternal king (T. Reub. 6:8-12). One text promises that Melchizedek would return to Zion 'to free them from the debt of all their iniquities' (11QMelch 2.6.).

36 Concerning the desecration of the Temple see Josephus, Ant., xx. 162-67. Consequently many anticipated a restored or rebuilt Temple (Tob. 14:5-6), especially the Qumran community (e.g. 11QTemple 29:8-10; 4QFlor 1:2-6). Ezekiel's description of a new glorious Temple (chs. 40-48) following the covenant renewal and restoration of Israel to the land under the rule of a Davidic king (chs. 36-37) also suggests a rebuilt Temple. See C.A. Evans, 'Jesus' Action in the Temple and Evidence of Corruption in the First-Century Temple', SBL Seminar Papers 28 (1989) 522-39 and 'Jesus' Action in the Temple: Cleansing or Portent of Destruction?' CBQ 51 (1989) 237-70. 
heavenly Jerusalem $(12: 22-24 ; 13: 14)$ where sacrifices of praise could now be offered (12:28; 13:15-16).

Although many of the Jewish eschatological hopes had 'already' been fulfilled in Christ, the author appeals to additional events that had 'not yet' come to pass. From our modern perspective, we know now that part of the 'not yet' was to be fulfilled in their distant future when Christ 'shall appear a second time for salvation without reference to sin' (9:28), resurrecting and glorifying those of faith still awaiting 'what was promised' (11:40). Our author also explains that the messianic Son had 'not yet' subjugated all things (2:7-9) including his enemies under his feet $(1: 13 ; 10: 11)$. This refers to the Jewish expectation that the coming Davidic Son would render judgement upon the wicked rulers and oppressors of God's people. ${ }^{37}$ It is this coming crisis that the author appeals to throughout his warnings.

\section{Descriptions of the Coming Crisis}

\section{a) The Burning of Land (Heb. 6:7-8)}

The author concludes his third warning (Heb. 6:4-8) with the pronouncement of judgement on the land that bears no fruit (vv. 7-8). Often interpreters explain this warning in light of the agricultural imagery found elsewhere in rabbinic sources ${ }^{38}$ and in the parables of Jesus. ${ }^{39}$ However, rather than an undefined piece of 'ground' as indicated by most translations, the word $\gamma \hat{\eta}$ is best understood here as a reference to 'the land' of Palestine for the following reasons. First, $\gamma \hat{\eta}$ is commonly used in the LXX for the Hebrew word denotes the land of covenant blessing in the Old Testament. This meaning corresponds to the covenant structure and Jewish outlook of the book. ${ }^{40}$ Second, the author uses $\gamma \hat{\eta}$ without an article elsewhere in the epistle to designate 'the land of promise' (e.g. 11:9). Third, the example of the Exodus generation first mentioned in Hebrews 3-4 and alluded to again in 6:4-6 suggests that the land which they

37 For example, see Dn. 7:22-27; 1 En. 46:1-6; 62:3-11; 4 Ezr. 12:31-33; 2 Esd. 13:29-38; 51-52.

38 See A. Vanhoye, 'Heb 6:7-8 et le mashal rabbinique', The New Testament Age, ed. W.C. Weinrich (FS B. Reicke; Macon: Mercer, 1984), 2:527-32.

39 These parables include those of the sower (Mt. 13:3-8), the tares (13:24-30), the mustard seed (13:31-32), and the vine and branches (Jn. 15:1-6).

40 The author's 17 uses of $\delta i \alpha \theta \dot{\eta} \kappa \eta$ ('covenant') account for over half of its NT occurrences $(30 \mathrm{x})$ illustrating the prominence of the concept in the epistle. 
forfeited is in view here in 6:7-8.41 Fourth, the 'curse' on the land in Hebrews 6:8 may allude to the growth of 'thorns and thistles' on the 'ground' $(\gamma \hat{\eta})$ as part of the 'curse' for Adam's disobedience in Genesis 3:17-18 (LXX). However, absent from Genesis 3 is the 'blessing' mentioned in Hebrews 6:7. The combination of blessing and curse corresponds more closely to Deuteronomy 11:26-28 where God offers the survivors of the wilderness generation two options: blessing for obedience or a curse for disobedience. A comprehensive list of the curses for covenant-unfaithfulness are given in Deuteronomy 28:15-68. The final curse would make the 'land $(\gamma \hat{\eta}-\mathrm{LXX}) \ldots$ a burning waste, unsown and unproductive' (29:23). Since the blessings of obedience were experienced in relation to the land (28:1-12), disobedience would result in the ultimate destruction of the land as the source of those blessings. Alluding to this Old Testament background, the author of Hebrews declares that the sacred land of the Jews would soon become a place of cursing and judgement. Rather than a reference to 'eternal condemnation' or 'final judgement' as some maintain, 42 the expression 'close to being cursed'

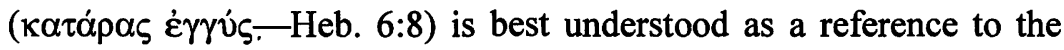
impending destruction of the Jewish homeland. Those believers seeking safety in Judaism are warned that the Jewish leaders had produced 'thorns and thistles' by their rejection and crucifixion of Christ and therefore their nation was doomed to be 'burned' (Heb. 6:8). This corresponds to the destruction brought upon the land during the Roman invasion to crush the Jewish revolt. ${ }^{43}$ Josephus reports

41 The warnings of Heb. 3:6-4:11 and 6:4-6 are linked by their common appeal to the example of the Exodus generation. This is demonstrated by the use of plural substantival participles to describe that generation in $3: 16-19 ; 4: 2,6$; which is resumed with the fourfold description of those in danger of falling away in 6:4-5 (see also 'those' referred to in 12:25). Notice the allusions to the experiences of the Exodus generation in 6:4: 'enlightened'-pillar of fire; 'tasted of the heavenly gift'-manna; 'partakers of the Holy Spirit'-the Spirit coming upon the 70 elders in Nu. 11:16-30; 'tasted the good word of God and the powers of the age to come'-receiving of the Law and Moses' confirmatory miracles (Gleason, 'The Old Testament Background of the Warning in Hebrews 6:4-8, 73-8; D. Mathewson, 'Reading Heb 6:4-6 in Light of the Old Testament', WTJ 61 (1999) 209-25).

42 Grudem, 'Perseverance of the Saints', 151, 155 and Toussaint, 'The Eschatology of the Warning Passages in the Book of Hebrews', 175.

43 Josephus in his Jewish Wars records his eyewitness account of the Roman invasion. The Jewish revolt began in AD 66 with the Jews' stopping the daily sacrifices in the Temple in honour of the emperor and the Jews' massacre of the Roman garrisons at Masada (ii. 405-410). Rome responded with a large-scale military campaign led by Cestius Gallus, governor of Syria, who with four legions at his disposal, quickly marched through Galilee and Samaria to Jerusalem (ii. 
Vespasian's policy to 'set fire, not only to the city itself, but to all the villas and small cities that were round about it' ( $J . W$., iii.132-34; cf. iv.488.). The Romans also devastated 'Galilee and the surrounding district' (J.W., vi.339). Describing the burning of the Temple, Josephus declares, 'You would have thought that the temple-hill was boiling over from its base, being everywhere one mass of flame' (J.W., vi.275). The Roman triumph celebrating the defeat of the Jewish state, portrayed it as 'a country still on every side in flames' (J.W., vii.145). Foreseeing this coming crisis, the author warns his readers that the land had become a place of judgement rather than blessing. This fits the force of his argument, for to return to the symbols of Judaism meant entering the realm of God's wrath.

\section{b) The Destruction of the Old Covenant (Heb. 8:13)}

In Hebrews 8:13, the author concludes that the arrival of the new covenant has made the first obsolete. Using two present participles he explains that the first covenant was now in the process of 'becoming obsolete' and 'growing old.' Its obsolescence would soon be complete

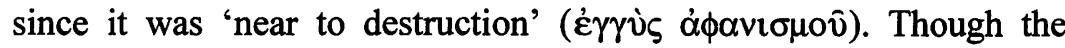
word á $\phi a v i \sigma \mu o$ oc occurs only here in the NT, it is used frequently in the LXX (56x) to describe the physical destruction of Israel (Je. 12:11; Ezk. 6:14; Mi. 7:13; Joel 2:13), Jerusalem (Je. 19:8) and the Temple (Dn. 9:26; Jdt. 4:12). It is never used to denote a gradual disappearance as suggested by most English renderings of Hebrews

499-532). He successfully pushed his attack up to the Temple walls before retreating northward from the city (ii. 533-45). Crediting their withdrawal to divine intervention, the Jews pursued the retreating Romans, inflicted many losses, and finally expelled them from Palestine (ii. 546-55). Nero then appointed Vespasian who entered Palestine in the spring of $\mathrm{AD} 67$ with three legions and a strong auxiliary force (iii. 64-69). His Roman troops slowly proceeded from the north through Galilee to subdue the now well-fortified cities of provincial Palestine. By the next year Vespasian had occupied most of the remaining towns around Jerusalem. His conquest of the city itself was prevented by his election to emperor and his departure with a large part of his army for Rome (iv. 592-621). Again the standstill of the Roman advance in AD 68-69 encouraged the Jewish defenders' confidence that they would ultimately prevail through divine deliverance (iv. 84-91). In the spring of $A D 70$ Titus, the eldest son of the new emperor, gathered his forces before the walls of Jerusalem to begin its final siege (v. 36-97). The Jewish patriots fought fiercely throughout the city, suffering terrible losses. Assured of imminent deliverance by God, they made their final stand in the Temple (vi. 285-87). When the Romans destroyed the Temple, Jewish resistance came virtually to an end (vi. 323-55; vii. 1-4). The physical suffering of the inhabitants of the city and surrounding towns was enormous. All ranks of Jewish society were severely affected, including the armed defenders slain in battle as well as the noncombatants subjected to hunger and disease from the sieges. 
8:13 (e.g. 'ready to disappear' NASB). To the contrary, it always denotes the demise of persons or things by violent means usually due to God's judgement. The author's point is that the superiority of the New Covenant would soon be sealed by the complete destruction of the Old Covenant including its priests, sacrifices and Temple.

\section{c) The Destruction of the Typological Sacrificial System (Heb. 10:9)}

The author concludes his extended exposition of the superiority and permanence of Christ's high priestly sacrifice by announcing the end of the typological sacrificial system. The NASB translation, 'He takes away (’่varpeî) the first in order to establish the second' (Heb. 10:9), fails to express the destructive force of ávaıpé $\omega$. This word was a technical term in classical Greek meaning to 'kill, do away with, murder, or execute.' 44 This classical meaning dominates its 23 occurrences in the NT where it is commonly used to denote 'killing by violence or execution'. ${ }^{45}$ Again the author chooses a fitting term to declare Christ's purpose to destroy the 'first' ( $\pi \rho \hat{\omega} \tau 0 \varsigma)$ in order to replace it with the second. The repeated use of 'first' ( $\pi \rho \hat{\omega} \tau \mathrm{\tau} / \mathrm{s})$ in the preceding context $(7: 2 ; 8: 7,13 ; 9: 1,2,6,8,15,18 ; 10: 9)$ indicates all the symbols of the first covenant are in view. Here again we find an allusion to the imminent crisis coming upon Israel. The transition from the first covenant to the second covenant was dramatically finalised in $\mathrm{AD} 70$ when the Romans destroyed the physical Temple and removed its symbols from the land. ${ }^{46}$ Many ancient historians both Jewish and Christian considered the destruction of Jerusalem as an act of God and the Romans as the agents of divine justice. ${ }^{47}$

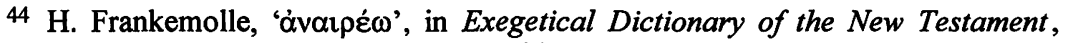
eds. H. Balz \& G. Schneider (Grand Rapids: Eerdmans, 1990), 1:81-82.

45 E.g. Herod's destruction of the male children of Bethlehem (Mt. 2:16); plots to put to death Jesus (Lk. 22:2), Peter (Acts 5:33), Paul (Acts 9:23); and the crucifixion of Christ (Lk. 23:32; Acts 2:23). Only once in Acts 7:21 is ávalpéw used without destructive overtones to denote how 'Pharaoh's daughter took ... away' Moses to protect him. See BAGD, 54-55.

46 Not only was the Temple burned and demolished (J.W., vi.249-53; 257-66; vii.1-4) but all the Temple furnishings including the gold vessels and purple veils were taken to Rome for display (J.W., vii.160-62).

47 Josephus records the confession of one surviving rebel leader, Eleazer, who attributed the burning of the city not to Rome but to God as punishment for their many sins (J.W., vii.332-33). Some early Christians considered the destruction of the Jewish leaders and their city as 'God's judgement ... for all their crimes against the Christ and his Apostles' (Eusebius, Hist. Eccl., 3.5.3.; cf. Ep. Barn. 16.1-2). 


\section{d) The Day Drawing Near (Heb. 10:25)}

Though the 'last days' (1:2) had begun, the author exhorts his readers to hold fast to their confession (10:23) because 'the day' ( $\tau \dot{\eta} \nu \dot{\eta} \mu \varepsilon \dot{\rho} \alpha \propto$ ) was yet approaching. Many claim that this can only refer to 'that ultimate eschatological day ... of Christ's return' (cf., 9:28).48 However, in the OT 'the day' was the common designation for a time of destruction coming upon the land of Israel due to covenantunfaithfulness (e.g. Is. 24:21; Ezk. 7:7; Zp. 1:14-18; Joel 1:15; cf. Mt. $24: 36$ ). The word 'day' is modified in several ways in this verse. First, the use of the article ( $\tau$ inv) points back to a definite crisis understood by the readers. In the context this would most naturally refer to the coming destruction of the land (6:6) and Old Covenant symbols mentioned earlier $(8: 13 ; 10: 9)$. Second, 'the day' is described as

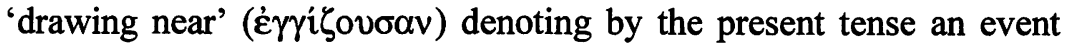
currently unfolding before the readers. This is consistent with the idiomatic expression-'day(s) drawing near'-used in the OT to denote an event that would occur immediately (e.g. nearness of death, Gn. 27:41; Dt. $31: 14 ; 1$ Ki. 2:1; 1 Mac. 2:49). Third, the eschat-

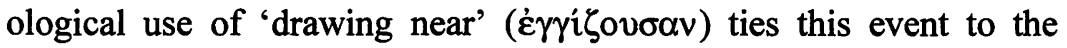

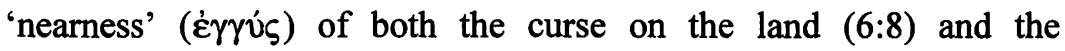
destruction of the Old Covenant symbols (8:13). Finally, the nearness of the coming crisis is confirmed by the words 'as you see' ( $\beta \lambda \varepsilon \dot{\pi \varepsilon \tau \varepsilon,}$ present indicative), indicating that signs of the coming crisis were already visible to the readers. This parallels Jesus' warning to his disciples 'when you see all these things, recognise that He is near

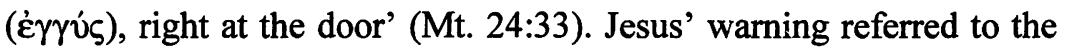
destruction of the Temple which occurred within the lifetime of his disciples (Mt. 24:1-15, 32-36). In like manner, the readers of Hebrews are urged to take heed to the warnings since they could see the crisis coming.

\section{e) The Shaking of Heaven (Heb. 12:25-27)}

The final warning appeals to the promise in Haggai 2:6 that God would 'Yet once more ... shake not only earth, but also the heaven.' Many have taken this to refer to a great 'cosmic catastrophe' that will bring an end to the created universe. ${ }^{49}$ However, in light of the

48 E.g. Hughes, Hebrews, 416.

49 E.g. Bruce, Hebrews, 383; Hughes, Hebrews, 558; Moffatt, Hebrews, 221-22. However, a 'cosmic catastrophe' bringing an end to the space-time universe is no longer assumed to be part of Jewish and early Christian eschatology by a growing number of scholars. For example, Wright argues that the cosmic language 
author's focus on the eschatological demise of the sacrificial system (Heb. 8-10); it seems best to understand the 'shaking of earth and heaven' as a symbolic description of the destruction of the Jerusalem Temple. 50 This is confirmed in the following ways. First, the Jews considered the Temple to be the focal point of creation - 'the Gate of Heaven' 51 and 'the Navel of the Earth.' 52 As such the Temple became a microcosm of the Jewish cosmology. The inner sanctuary was designed to symbolise 'heaven' with the outer court representing the earth and the sea. ${ }^{53}$ Both Josephus and Philo utilise this cosmic symbolism, declaring, for example, the veil to represent heaven and the seven lamps to represent the 'seven' planets. ${ }^{54}$ Later Talmudic tradition taught that the walls of the Temple resembled 'the waves of the sea.' 55 The Jewish connection between Temple and cosmos was such that the glory of the Temple in Jerusalem symbolised the stability of the Jewish world. Second, the context of Haggai also suggests temple symbolism because the prophet declares that 'the heavens and the earth' will be shaken in order to establish a greater more glorious Temple (Hag. 2:6-9). This is consistent with the use of temple symbolișm throughout the OT. ${ }^{56}$ Third, cosmic imagery is

describing the coming of the new age should not be understood literally but regarded as metaphorical accounts of the destruction of Jerusalem and the worldwide cataclysmic events leading up to it. 'It was after all the Stoics, not the firstcentury Jews, who characteristically believed that the world would be dissolved in fire. ... Far more important to the first-century Jew than questions of space, time and literal cosmology were the key issues of Temple, Land, and Torah.' See The New Testament and the People of God, 280-86.

50 Others who link the 'shaking of the heavens' (Heb. 12:25-27) to the destruction of the Temple include Hurst, 'Eschatology and "Platonism" in Hebrews', 70-71 and C.H.T. Fletcher-Louis, 'The Destruction of the Temple and the Relativization of the Old Covenant', The Reader Must Understand: Eschatology in Bible and Theology ed. K.E. Brower \& M.W. Elliott (Leicester: Apollos, 1997), 162, n. 58.

51 M. Barker, The Gate of Heaven: The History and Symbolism of the Temple in Jerusalem (London: SPCK, 1991). See also R. Patai, Man and Temple in Ancient Jewish Myth and Ritual (New York: KTAV, 1967), 105-39.

52 B.F. Meyer, 'The Temple at the Navel of the Earth', Christus Faber: The Master-builder and the House of God (Allisen Park: Pickwick, 1992), 217-79.

53 A Jewish midrash declared, 'The court surrounds the Temple just as the sea surrounds the world' (Numbers Rabbah 13:19).

54 Josephus, J.W., v.146, 212-213, 217; Ant. iii.123, 138-44; 179-87; and Philo, Questions on Exodus, 2:85; Life of Moses, 2:88, 103.

55 See Baba Bathra, 4a and Sukkah, 51b.

56 For example, Psalm 78:69 declares, 'He built his sanctuary like the high heavens, like the earth, which he has founded forever' (RSV). The structure of the tabernacle was meant to depict heaven that was 'like a tent' (Ps. 104:2; Is. 40:22). Temple-symbolism may also explain why during the dedication of the Temple Solomon addressed God 'in this house' and 'in heaven' at the same time (1 Ki. 
used elsewhere in the NT to describe the destruction of the Jerusalem Temple. For example, Jesus summarised his prediction of the Temple's destruction with the promise 'Heaven and earth will pass away' (Mt. 24:35; Mk. 13:31; Lk. 21:33). ${ }^{57}$ Fourth, the author's own use of cosmic symbolism throughout his epistle also indicates that the Temple's destruction is in view. ${ }^{58}$ For example, the author declares that the earthly tabernacle is 'a copy and shadow of the heavenly things' (Heb. 8:5; cf. 9:23). Since the veil before the Holy place typified 'heaven,' the author declares Jesus passed 'through the heavens' (4:14), that is 'through the veil' $(10: 19$; cf. 6:19), to offer his sacrifice. 59 This also explains why the author describes 'heaven' in Hebrews 12:27 as something 'made' ( $\pi$ olé $\omega$ ) of this creation, like the Holy place 'made with hands' ( $\chi \varepsilon i p o \pi$ oin $\tau \circ \varsigma$ ) spoken of in Hebrews $9: 24$. In this way, he distinguishes the symbol of 'heaven' which is about to be shaken (i.e. the Temple) from 'heaven itself' $(9: 24)$ where the true holy place is found - 'the perfect tabernacle, not made with hands, ... not of this creation' (Heb. 9:11). The 'heavens' and 'the earth' of Psalm 102 cited in Hebrews 1:10-12 may also refer to the Jerusalem Temple since the psalm's original purpose was to lament the destruction of Solomon's Temple. Notice the Jewish exiles in Babylon are reminded in the psalm that even though the 'stones' of Zion lay in 'dust' (Ps. 102:13-14) they should not despair. Even though 'earth' and 'heaven (i.e. the Temple) ... perish ... [and] wear out,' yet 'Thou does endure'- 'Thou art the same and Thy years will not come to an end' (Ps. 102:26-27). In a similar way the author of Hebrews appeals to Psalm 102 to assure his readers of the stability of Christ as they witness the demise of the Herodian Temple. Finally, the 'shaking of heaven' anticipates the author's final appeal to his contemporary readers to 'go ... outside the camp' (Heb. 13:13) where

8:33-34). Elsewhere the creation of 'new heavens and a new earth' is equated with the creation of a new 'Jerusalem' (Is. 65:17-18).

57 Note the inclusio connecting the passing away of 'Heaven and earth' with the reference to the destruction of the Temple at the beginning of Jesus' discourse (Mt. $24: 2$; Mk. 13:2; Lk. 21:6). For a convincing argument that the passing away of 'heaven and earth' is best understood as the 'collapse of a mythical space-time universe which is embodied in the Jerusalem Temple', see Fletcher-Louis, 'The Destruction of the Temple and the Relativization of the Old Covenant', 145-69.

58 For further discussion see G.W. MacRae, 'Heavenly temple and eschatology in the letter to the Hebrews', Semeia 12 (1978) 179-199.

59 According to Josephus, the blue, purple, and crimson fabric of the veil covered with cherubim (Ex. 26:31; 36:35) was meant to symbolise heaven (J.W., v.212-13; cf. Philo, Questions on Exodus, 2.85). Hence, to enter through the Temple veil into the Holy Place was to enter into heaven itself, the very presence of God. See Barker, The Gate of Heaven, 105-111. 
Jesus suffered (13:11); that is, leave Jerusalem, 'for here we do not have a lasting city' (13:14) since Jerusalem would soon be destroyed.

\section{The Warning of Hebrews 10:26-31}

Hebrews 10 begins and ends with two OT citations depicting the immediacy of Christ's coming judgement. Quoting from Psalm 40:6-8 the author explains that Jesus Christ has 'come to do Thy will,' that is to destroy 'the first in order to establish the second' (Heb. 10:9). He concludes the chapter with an appeal to Habakkuk 2:3-4 warning that Jesus Christ 'will come and not delay' (Heb. 10:37). These announcements of Christ's coming judgement provide the OT framework for his warning in Hebrews 10:26-31. Throughout this section the author appeals to numerous OT scriptures to illustrate the danger faced by his readers if they abandon their 'confidence' in the sufficiency and permanence of Christ's sacrifice $(10: 19,35)$. As we examine these passages, it is important that we keep in mind the broader OT context to the single verses or phrases cited. For, as Greg K. Beale observes, NT authors practiced a 'contextual exegesis' by 'quoting individual references as signposts to the broad redemptive-historical theme(s) from [their] immediate and larger OT context. ${ }^{\prime} 60$ As in the earlier warnings, ${ }^{61}$ the broader contexts of OT citations and allusions are crucial in determining the meaning of this warning.

\section{a) The Wilful Sin (Heb. 10:26)}

For if we go on sinning willfully after receiving the knowledge of the truth, there no longer remains a sacrifice for sins (NASB).

Many have recognised the warning against 'sinning wilfully' (10:27) as an allusion to the defiant sin of Numbers 15:30-31 and presumptuous sin of Deuteronomy 17:12. The word غंkovoícs ('wilfully') denotes the deliberate intent to disregard God's law. This is illustrated in the context of Numbers 15 with the example of the

60 G.K. Beale, 'Did Jesus and his followers preach the right doctrine from the wrong texts?' Themelios 14 (1989) 90-91. R.B. Hays sees this pattern as fundamental to Paul's intertextuality. He defines it as a 'metalepsis' whereby the author 'places the reader within a field of whispered or unstated correspondences' (Echoes of Scripture in the Letters of Paul [New Haven: Yale UP, 1989], 20). See also C.H. Dodd, According to the Scriptures (London: Nisbet, 1952), 126-27 and Bruce, Hebrews, 46.

61 See Gleason, 'The Old Testament Background of the Warning in Hebrews 6:4-8', and idem, 'The Old Testament Background of Rest in Hebrews 3:7-4:11.' 
man found picking up sticks on the Sabbath (Nu. 15:32-36). Since his action was a clear violation of the Sabbath Law (Ex. 35:4), the penalty was severe, 'the person shall be cut off,' that is 'put to death' (Ex. 31:14-15). In the warning of Hebrews, the author clearly had this physical penalty in mind because he mentioned in the following verse the need for 'two or three witnesses' (Heb. 10:28) to confirm a capital offense (cf. Dt. 17:6). Far from a public repudiation of belief in God, the sin in view here as indicated by the OT context denotes any deliberate act of covenant unfaithfulness including even the seemingly harmless act of picking up sticks on the Sabbath. The gravity of the sin is determined by the defiant attitude with which it is committed. However, the penalty is not eternal damnation but rather physical punishment resulting in death.

\section{b) The Consuming Fire (Heb. 10:27)}

But a certain terrifying expectation of judgment, and the fury of a fire which will consume the adversaries (NASB).

The author clarifies the 'terrifying' nature of the coming 'judgement' by citing Isaiah 26:11. His graphic warning alludes to Yahweh's 'uplifted hand' (26:11a) ready to strike judgement upon 'his enemies' (26:11b). A close examination of the context reveals that Isaiah's warning corresponds well to the threats facing first-century Jews living in the land of Israel. ${ }^{62}$ Known as the 'Apocalypse of Isaiah,' chapters 24-27 are considered a prophetic unit. The judgement beginning in chapter 24 declares that the Lord 'lays waste,' 'devastates,' (v. 1) and 'devours' (v. 5) the land (Y people of the land (i.e. the Jews) have 'transgressed laws, violated statutes, [and] broke the everlasting covenant' (v. 5). ${ }^{63}$ Hence, 'a curse' will devour the land (Y) and 'burn' its inhabitants (i.e. the Jews) because they are 'held guilty'(v. 6). ${ }^{64}$ The wider context of

62 Although most view Isaiah's prediction here to refer to God's judgement upon the nations of the world (e.g. J.N. Oswalt, Isaiah 1-39 [Grand Rapids: Eerdmans, 1986], 437f; G.W. Grogan, 'Isaiah', in The Expositor's Bible Commentary, ed. F.E. Gaebelein [Grand Rapids: Zondervan, 1986], 6:163-65; and E.J. Young, The Book of Isaiah, 3 Vols. [Grand Rapids: Eerdmans, 1969], 2:203-17), others see the judgement to include disobedient Jews living in the land of Israel (e.g. J.D.W. Watts, Isaiah 1-33 [Waco: Word, 1985], 294-351).

63 The references to priests (24:2), laws (ת) 'everlasting' Noahic covenant (Gn. 9:16) in favour of the 'everlasting' Mosaic covenant (Lv. 24:8).

64 Watts maintains that 'the land' in Isaiah 24-26 'was particularly Israel's land' (Isaiah 1-33, 317). This is confirmed by references to Zion, Jerusalem (24:23), and the land of Judah (26:1). The section concludes by declaring the extent of 
Isaiah 26 indicates the consuming fire does not refer to 'the fire of eternal punishment,' 65 but rather to physical destruction coming upon the land of Israel and its Jewish inhabitants.

The author introduces several changes in Isaiah 26:11b (LXX) to heighten its impact upon his audience. First, he abridges the LXX text, by using the noun 'zeal' ( $\zeta \hat{\eta}_{0} \varsigma$ ) from the middle clause to modify the noun 'fire' ( $\pi \hat{v} \rho$ ) of the final clause, resulting in a 'fiery zeal' ( $\pi$ voò $\zeta \hat{\eta} \lambda \circ \varsigma)$. He thereby identifies Yahweh as the source of both the 'zeal' that 'will take away by violence his foolish people (i.e.

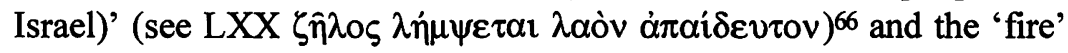

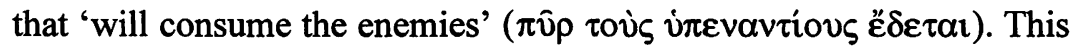
change links Yahweh's 'foolish people' ( $\lambda \alpha$ òv à $\pi \alpha i \delta \varepsilon v \tau o v)$ with their 'enemies' as the objects of God's wrath. ${ }^{67}$ This fits the context of Isaiah 26-27 where God's wrath comes upon the people of Israel. Second, he changes the form of the verb 'consume' from future

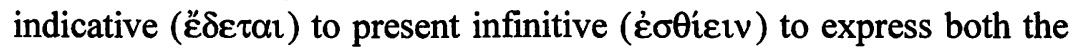
fire's purpose to consume (by the infinitive) and its occurrence simultaneous with the time of writing (by the present tense). Hence, rather than a future event the fiery judgement is viewed as a present reality by the author of Hebrews. Later in Hebrews 10:37 he again appeals to Isaiah 26 , this time using the phrase 'a very little while' ( $\mu$ ккрòv öбov öбov) in verse 20 to stress the urgency of the immediate crisis facing his readers. No doubt he indented his readers to recall the rest of Isaiah's warning, 'Come, my people, ... Hide for a little while until the indignation is past' (Is. 26:20 NASB).

Often in the OT 'fire came from the Lord' to consumed his people due to their covenant-unfaithfulness. Examples abound in the Pentateuch ranging from the complaining people of the Exodus $(\mathrm{Nu}$. 11:1-2) to Korah and his 250 companions ( Nu. 16:34), including Aaron's two sons, Nadab and Abihu (Lv. 10:1-2). Similarly, Moses

judgement from 'the Euphrates to the brook of Egypt' (27:12) which corresponds to the land originally promised to Abraham (Gn. 15:18). Hence, the repeated references to the 'the inhabitants of the land' (Is. 24:6; 26:9,18, 21) would include disobedient Jews living in 'the land' (Y) Grogan argues that $Y$ ('eres) means 'earth' not 'land' in Isaiah 24-27 because of its parallelism with 'תר ('world') in $24: 4$ (idem, 'Isaiah', 151). However, often רָרֵ is used as a poetic synonym for

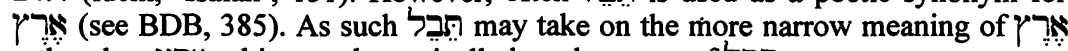
rather than אתר taking on the typically broader sense of

65 Young agrees that eternal punishment is not in view here (Isaiah, 2:217).

66 The term $\lambda \dot{\eta} \mu \psi \varepsilon \tau \alpha \iota$ (from $\lambda \alpha \mu \beta \alpha^{\prime} v \omega$ ) commonly denotes 'to take away or remove' by violence or force (e.g. Jos. 11:19; Judg. 8:16; $2 \mathrm{Ki}$. 2:5).

67 The term 'enemies' (צֵר) is used similarly by Isaiah to refer to rebellious Israel in $1: 24$. 
'warns' the new generation of Israel coming out of the wilderness (Dt. $32: 45$ ) that if they are unfaithful to the covenant Yahweh will 'burn' their land (Dt. 32:21-22) and 'consume' them by a 'burning heat' (Dt. $32: 24)$ as he did to some from the previous generation. Rather than a description of eternal damnation, fire is the common method of physical judgement for covenant unfaithfulness throughout the OT.

\section{c) A Severer Punishment (Heb. 10:29)}

How much severer punishment do you think he will deserve who has trampled under foot the Son of God, and has regarded as unclean the blood of the covenant by which he was sanctified, and has insulted the Spirit of grace. (NASB)

Here the author further identifies the sin he warns against. First, his readers are warned not to 'trample under foot the Son of God.' The word 'trampled' ( $\kappa \alpha \alpha \pi \alpha \tau \varepsilon$ ' $\omega$ ) is used elsewhere in the NT to denote treating something of great value as if it were worthless (pearls before swine-Mt. 7:6) or powerless (e.g. unsavoury salt-Mt. 5:13; unproductive seed-Lk. 8:5). The title 'Son of God' as used in Hebrews recalls the unique status of Christ as God's final revelation (1:2), the great High Priest $(4: 14 ; 7: 3)$ who secured permanent cleansing through his 'perfect' sacrifice $(5: 8 ; 7: 28)$. Hence, failure to acknowledge the unique superiority of Christ over other revelations (e.g. the Mosaic Law), priests (e.g. Levites), or sacrifices (e.g. of bulls and goats) is in effect to 'trample under foot the Son of God.' This meaning is confirmed by the second warning not to regard as 'unclean the blood of the covenant.' The key term korvós ('unclean') could be used here in the sense of 'common' thereby warning them not to treat 'the blood of the covenant' as a common sacrifice like the others offered by human priests. Or it may be understood in the OT sense of 'cultic impurity' implying that Christ's sacrifice could not fully provide purification for sins. In either case, it does not suggest a total repudiation of Christ but rather treating His sacrifice as if it had no more cleansing value than other sacrifices. They are also warned against insulting 'the Spirit of grace.' In the context of Hebrews the Spirit is the one who 'offered the blood of Christ without blemish to God' (9:14) and 'bears witness ' to the superiority of His revelation $(2: 3-4)$ and covenant $(10: 15)$. To degrade such things by returning to Judaism would 'outrage' the Spirit (RSV), thereby incurring God's wrath.

The word $\tau \mu \omega \omega$ pia ('punishment') found only here in the NT, occurs 15 times in the LXX and often in secular Greek. It is a general 
term for physical punishment ranging from flogging (Pr. 19:29) and imprisonment (1 Esd. 8:24) to physical death (Dn. 2:18). Though often purely vindictive in intent, $\tau \mu \omega \omega$ pí sometimes denotes punishment for the purpose of divine 'discipline.' For example, referring to the sufferings of the Jews under Ptolemy, the readers are urged in 2 Maccabees 'to recognise that these punishments ( $\tau \mu \omega \rho i \alpha \varsigma$ ) were designed not to destroy but to discipline ( $\pi \alpha 1 \delta \varepsilon i \alpha v)$ our people' (2 Mac. 6:12). The author of Hebrews argues from the lesser to the greater to warn that a greater sin requires a greater punishment. Since the penalty under the Mosaic Law was physical death (Heb. 10:28; cf. Dt. 17:6,12), some assume that a 'much severer punishment' must refer to spiritual death. ${ }^{68}$ However, the author leaves the nature of the punishment undefined. We are left to the OT examples of fire $(\mathrm{Nu}$. $11: 1-2 ; 16: 34)$ and stoning (Nu. 15:29-36) to fill in the meaning. The severity of the punishment does not require spiritual death for several reasons. First, the passage gives no indication of eternal condemnation resulting in spiritual death. Second, the OT citations and allusions consistently describe the threat of physical death. Third, rather than greater in 'kind' (i.e. spiritual death rather than physical death), the severity could refer to a physical punishment greater in degree or force than that previously experienced by the OT examples. This meaning corresponds well to the historical setting of Hebrews in light of the unprecedented suffering experienced during the Jewish war as noted by Josephus. Concerning the indescribable atrocities suffered by the Jews, he writes, 'To narrate their enormities in detail is impossible; but, to put it briefly, no other city ever endured such miseries' (J.W., v.442). The crucifixions of Jewish prisoners by the Romans were so numerous 'that space could not be found for the crosses nor crosses for the bodies' (J.W., v.451). In the end thousands upon thousands of Jews lost their lives and thousands more were enslaved. In the preface to his Jewish War, Josephus declares:

The war of the Jews against the Romans [was] the greatest not only of the wars of our own time, but, so far as accounts have reached us, well nigh of all that ever broke out between cities or nations. ... Indeed, in my opinion, the misfortunes of all nations since the world began fall short of those of the Jews $(J . W ., \mathrm{i} .1,12)$.

In Hebrews, the readers are warned not to find refuge in Judaism because of the unparalleled devastation soon to be brought upon the Jews by the Romans. If they failed to heed this warning, history

68 E.g. Bruce, Hebrews, 260. 
testifies that the severity of their physical punishment would have far surpassed that experienced by those stoned under the Mosaic Law or burned during the wilderness wanderings.

\section{d) The Lord's Vengeance and Judgement (Heb. 10:30)}

For we know Him who said, 'Vengeance is Mine, I will repay.' And again, 'The Lord will judge His people.' (NASB)

The author drove home his warning by alluding to the song of Moses in Deuteronomy 32. This song served as a poetic reminder of the curses earlier promised by Moses for covenant unfaithfulness (Dt. 28:15-68). Moses wanted to assure the second generation coming out of the wilderness that their possession of the 'land' was conditioned upon their faithfulness to the stipulations of the covenant. If they chose to disregard their covenant obligations, Yahweh promised to kindle 'a fire' against them and 'consume the land' (Dt. 32:22). The Lord would 'heap misfortunes on them' and they would be 'wasted by famine' and 'consumed by burning fire' (Dt. 32:23-25). ${ }^{69}$ In similar fashion, the author of Hebrews cites two phrases from Moses' song to warn his readers. The first follows a version of Deuteronomy 32:35a (LXX) cited also by Paul in Romans 12:19, 'Vengeance is mine, I will repay. ${ }^{70}$ A second phrase is recorded verbatim from Deuteronomy 32:36, 'the Lord will judge His people. '71 Placed between these two

69 See the Hebrew text that says literally they shall be 'devoured with burning

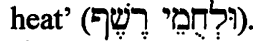

70 The word $\square$, to similarly used elsewhere to refer to God's vengeance coming upon his people due to covenant unfaithfulness (Ex. 21:20, 21; Lv. 26:25; Ps. 99:8; Is. 1:24; Je. 5:9, 29; 9:8; Ezk. 24:8).

71 Most English versions (e.g. NASB, NIV) translate this phrase 'The Lord will vindicate his people' by destroying Israel's enemies. However, this hardly fits the way the author is using the phrase in Heb. 10:30. His intent is not to comfort his readers with the fact that the Lord will vindicate them but rather to warn them of coming judgement upon them. The positive rendering of 'vindicate' in Dt. 32:36 assumes a synonymous parallelism with the following phrase- ' $[\mathrm{He}]$ will have compassion on His servants' (v. 36b). However, the grammar could just as easily express an antithetical parallelism, e.g. 'The Lord will judge his people, but he will have compassion on His servants (i.e. those faithful to the covenant).' The latter translation seems best for several reasons. First, in parallel structures, the waw followed by the noun rather than verb can express an adversative relationship, in this case, contrasting 'judge' (negative) with 'have compassion' (positive). Second, though the Hebrew verb negative connotation of disciplinary judgement (e.g. Gn. 15:14; Dt. 32:36; 1 Sa. 2:10; Ps. 110:6; Is. 3:13). This fits the context of Dt. 32 that describes physical judgement rather than vindication coming upon Israel because of their apostasy (v. 15-33). This also fits the purpose of the passage to provide a 'warning' rather than a comfort to the people of Israel (32:46) as they prepare to possess the land. 
phrases in the LXX is the warning that 'the day of their destruction is

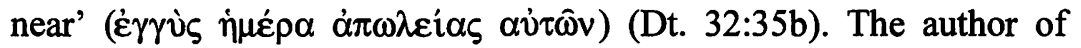
Hebrews' allusion to the 'nearness' of 'the day' (Heb. 10:25) and coming 'destruction' (Heb. 10:39) is unmistakable. The people of Israel had again proven their unfaithfulness to the covenant, this time by rejecting their Messiah, and, therefore, 'the day' of their 'destruction' as promised by Moses (Dt. 32:35b) was 'near.' For his readers to avoid 'the day' of 'vengeance,' 'judgement,' and 'destruction' coming upon Israel, the author of Hebrews exhorts them to hold firm to their confession and not 'shrink back' into reliance upon the Jewish sacrifices for cleansing.

\section{e) Falling into the Hands of God (Heb. 10:31)}

It is a terrifying thing to fall into the hands of the living God.

The warning against 'falling into the hands of the living God' (

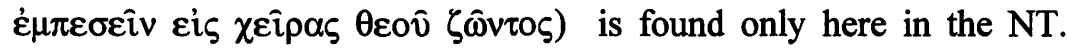
This idiom for divine judgement finds its closest OT parallel in David's plea to the prophet Gad in 2 Sa. 24:14 (LXX - 2 Ki. 24:14),

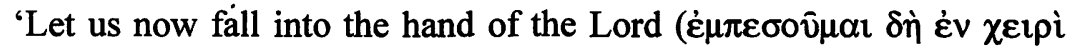
Kupiov) for His mercies are great.' Both passages use the same aorist verb (غ̇vé $\pi \varepsilon \sigma o v)$ and anthropomorphic reference to God's 'hand[s]' ( $\chi \varepsilon i \rho)$ of judgement. However, David uses the expression to appeal to God's mercy while the author of Hebrews warns of God's severity. This apparent discrepancy can be explained by the broader context of David's judgement. Rather than experiencing the mercy of God as David had hoped, his choice of a three day plague resulted in the deaths of 70,000 Israelites (2 Sa. 24:15). David's sin against God in numbering the people took a surprisingly severe toll. In the end, David came to understand the terror of falling into the hands of God. Notice that the judgement resulted not in eternal damnation but rather physical death. For how could God eternally condemn 70,000 innocent Israelites for David's sin (cf. 2 Sa. 24:17)? Yet the judgement came upon those living in the land-'from Dan to Beersheba' (2 Sa. 24:15). Again the author of Hebrews used a fitting OT example to warn of the devastation coming on the land of Israel that would result in the physical deaths of many.

\section{Conclusion}

The OT examples of physical judgement and absence of NT damnation terminology in Hebrews 10:26-31 suggests that eternal 
destruction is far from the author's intended meaning. Furthermore, to limit the warning to a distant future judgement overlooks its nearness and diminishes its relevance to the first-century audience facing the immediate threat of the Jewish war and Roman invasion. The descriptions of the coming crisis throughout the epistle point immediately to the destruction of Jerusalem and the Temple as predicted by Jesus (Mt. 23:37-24:28; Mk. 13:1-32; Lk. 21:5-36). By rejecting their Messiah, the Jewish leaders of that generation had become the 'adversaries' of God and were therefore under his wrath. The author warns his readers not to shrink back into the destruction coming upon their 'adversaries' (i.e. those Jewish leaders who persecuted them) but to preserve their lives by persevering in their faith (10:39). ${ }^{72}$ They could avoid God's wrath coming upon 'his people' by holding firm to their confession, bearing the reproach of Christ outside the camp (13:13), and looking to the heavenly city instead of the earthly one (i.e. Jerusalem) now under the sentence of destruction (13:14). ${ }^{73} \mathrm{We}$ can apply this warning to the modern reader in a manner similar to the way that the ancient author applied OT examples to his NT audience. Just as God physically judged his people when they lapsed into unbelief in both the OT and NT, he may likewise severely punish his people today when they disregard their confession of faith in Christ and drift away from his life sustaining presence.

72 The author's warnings of the disastrous consequences of lapsing back into Judaism had application even to Christians of the Jewish Diaspora, for the threat of judgement was not limited only to the Jewish homeland. Josephus records how the wrath of Rome was felt in other centres of the Jewish Diaspora. For example, Roman legions were permitted to kill thousands of Jews living in Alexandria and to burn their homes (J.W., ii.494-98). Following the revolt, the Jews of Antioch also suffered greatly under Titus (J.W., vii.37-38, 46-53).

73 This interpretation of the warnings corresponds to Eusebius' remarkable account of how the Christian community in Jerusalem was warned to leave the city before its destruction: 'The people of the church in Jerusalem were commanded by an oracle given by revelation before the war to those in the city who were worthy of it to depart and dwell in one of the cities of Perea which they called Pella. To it those who believed on Christ migrated from Jerusalem, that when holy men had altogether deserted the royal capital of the Jews and the whole land of Judaea, the judgement of God might at last overtake them' (Hist. Eccl., 3.5.2-3). For a defense of the historicity of this account, see E. Yamauchi, 'Christians and the Jewish Revolts against Rome', Fides et Historia 23 (1991) 18-22. 